\title{
PENGARUH PENERAPAN MODEL PEMBELAJARAN ROLE PLAYING TERHADAP HASIL BELAJAR ILMU PENGETAHUAN SOSIAL (IPS) PADA MURID KELAS V
}

\author{
Hairul Anwar, Syahribulan, Muhammad Basri \\ Pendidikan Guru Sekolah Dasar, Fakultas Keguruan dan Ilmu Pendidikan \\ Universitas Muhammadiyah Makassar \\ Iqramsyar34@gmail.com
}

\begin{abstract}
ABSTRAK
Jenis penelitian ini adalah penelitian eksperimen bentuk Pre Test Post Test Design yaitu sebuah eksperimen yang dalam pelaksanaannya hanya melibatkan satu kelas sebagai kelas eksperimen tanpa adanya kelas pembanding (kelas kontrol). Tujuan penelitian ini yaitu untuk mengetahui pengaruh penerapan model pembelajaran role playing terhadap hasil belajar pada mata pelajaran Ilmu Pengetahuan Sosial murid kelas V SD Inpres Bontomanai Kota Makassar tahun ajaran 2016. Satuan eksperimen dalam penelitian ini adalah murid Kelas V sebanyak 24 orang. Penelitian dilaksanakan selama 5 kali pertemuan. Tahapan penelitian ini yaitu tes awal (pretest), pemberian perlakuan (treatment) dan tes akhir (posttest) Keberhasilan proses pembelajaran ditinjau dari ketercapaian ketuntasan hasil belajar IPS apabila secara klasikal 17 dari 24 murid yang mencapai dan melebihi nilai KKM yaitu (65) $\geq 70 \%$, aktivitas murid dalam pembelajaran IPS yaitu $70 \%$ murid yang aktif dalam pembelajaran. Teknik pengumpulan data yang digunakan adalah data skor perolehan hasil belajar murid yang dikumpulkan dengan menggunakan pretest dan posttest, data tentang aktivitas murid dalam pembelajaran IPS dikumpulkan dengan menggunakan lembar observasi aktivitas belajar murid. (Terlampir) Data dianalisis dengan analisis statistik deskriptif penerapan model pembelajaran Role Playing (Bermain Peran), hasil belajar murid dengan menggunakan model pembelajaran Role Playing (Bermain Peran) menunjukkkan hasil belajar yang lebih baik dari pada sebelum diterapkan model pembelajaran Role Playing (Bermain Peran). Hasil analisis statistik inferensial menggunakan rumus uji t, diketahui bahwa nilai $t_{\text {Hitung }}$ yang diperoleh adalah 42,70 dengan frekuensi $\mathrm{db}=24-1=23$, pada taraf signifikansi 5\% diperoleh $\mathrm{t}_{\text {Tabel }}=2,14$. Jadi, $\mathrm{t}_{\text {Hitung }}>\mathrm{t}_{\text {tabel }}$ atau hipotesis nol $\left(\mathrm{H}_{0}\right)$ ditolak dan hipotesis alternative $\left(\mathrm{H}_{1}\right)$ diterima. Kesimpulan membuktikan bahwa ada pengaruh penerapan model pembelajaran role playing terhadap hasil belajar pada mata pelajaran IPS murid kelas V SD Inpres Bontomanai Kota Makassar.
\end{abstract}

Kata kunci: Eksperimen, Model Pembelajaran Role Playing (Bermain Peran) 


\section{PENDAHULUAN}

Untuk menunjang keberhasilan proses belajar megajar, seorang guru harus memiliki kompetensi profesional, yaitu guru harus mampu mengolah materi dan mampu menciptakan proses pembelajaran yang menarik dan menyenangkan sehingga murid antusias untuk menerima pelajaran. Idealnya dalam proses pembelajaran IPS murid diajak untuk melihat realita keadaan di sekitarnya dan memberikan pengalaman yang membekas di benak murid. Murid diajak terjun langsung di daerah sekitarnya untuk mengamati fakta dan ikut serta memanfaatkan sumber daya alam secara optimal.

Rendahnya hasil belajar yang dicapai murid tidak semata-mata disebabkan oleh kemampuan murid, tetapi bisa juga disebabkan kurang berhasilnya guru dalam mengajar. Karena salah satu tugas guru adalah sebagai pengajar yang lebih menekankan kepada tugas dalam merencanakan dan melaksanakan pengajaran. Dalam hal ini guru dituntut memiliki seperangkat pengetahuan dan keterampilan teknis mengajar, disamping menguasai ilmu atau bahan yang akan diajarkan. Dalam pembelajaran terdapat tiga komponen utama yang saling berpengaruh dalam proses belajar-mengajar. Ketiga komponen tersebut adalah: kondisi pembelajaran, metode pembelajaran, dan hasil pembelajaran. Terkait tentang ketiga komponen tersebut maka guru harus mampu memadukan dan mengembangkannya, agar kegiatan pembelajaran menuai hasil yang maksimal. Oleh karena itu, dengan bekal kemampuan dan keterampilan yang dimiliki guru diharapkan mampu menjadikan pembelajaran lebih menarik dan menyenangkan, sehingga memperoleh hasi belajar yang optimal.

Oleh karena itu, sebagai seorang guru harus dapat menentukan strategi yang paling cocok untuk digunakan dalam pembelajaran meskipun tidak dapat dipungkiri jika dalam penggunaan strategi tersebut terdapat kekurangan. Untuk tujuan inilah guru harus memiliki keberanian untuk melakukan berbagai uji coba terhadap suatu metode mengajar, membuat suatu media murah atau penerapan suatu strategi mengajar tertentu yang secara teoritis dapat dipertanggung jawabkan untuk memecahkan permasalahan pembelajaran.

Namun, kenyataan menunjukkan bahwa hasil belajar murid masih sangat rendah. Rendahnya hasil belajar ini secara tidak langsung akan berpengaruh 
buruk dalam peningkatan Ilmu Pengetahuan dan Teknologi yang kemudian berakibat pada rendahnya mutu manusia yang dihasilkan, oleh karena itu, diperlukan sebuah sistem untuk memperbaikinya. Rendahnya hasil belajar terjadi karena murid mengalami beberapa kesulitan ketika sedang belajar.

Rendahnya hasil belajar IPS murid kelas V SD disebabkan karena murid merasa kesulitan dalam menerima pelajaran IPS, pembelajaran IPS menjadi momok bagi murid karena materi ajar yang begitu banyak dan penyampaian materi dari guru masih menggunakan model pembelajaran klasik, seperti ceramah, guru mencatat di papan tulis dan murid menyalin apa yang ditulis oleh guru, guru sangat jarang melakukan umpan balik dengan murid, pembelajaran bersifat monoton yang mengakibatkan murid bersifat pasif, guru jarang menggunakan media pembelajaran dan jarang memberikan permainan dalam belajar, peranan pembelajaran lebih banyak dipegang oleh guru Sehingga murid merasa bosan yang mengakibatkan turunnya prestasi belajar murid.

Dilihat dari hasil belajar IPS pada murid kelas V SD Inpres Bontomanai Kota Makassar tersebut, maka dianggap perlu dilakukan penelitian dengan penerapan Model Role Playing (Bermain Peran). Sehingga diharapkan pembelajaran tidaklah menjemukan, murid akan merasa nyaman dalam proses pembelajaran, dengan demikian materi yang disampaikan akan mudah diterima oleh murid.

Berdasarkan uraian di atas rumusan masalah dalam penelitian ini adalah "Apakah model pembelajaran Role Playing berpengaruh terhadap hasil belajar Ilmu Pengetahuan Sosial murid kelas V SD Inpres Bontomanai Kota Makassar?". Untuk mengetahui model pembelajaran Role Playing berpengaruh terhadap hasil belajar Ilmu Pengetahuan Sosial murid kelas V SD Inpres Bontomanai Kota Makassar.

\section{Ilmu Pengetahuan Sosial di SD}

Ilmu Pengetahuan Sosial (IPS) merupakan salah satu mata pelajaran yang diberikan mulai dari SD sampai perguruan tinggi. IPS mengkaji seperangkat peristiwa, fakta, konsep dan generalisasi yang berkaitan dengan isu sosial. Pada jenjang SD/MI mata pelajaran IPS memuat materi Geografi, Sejarah dan Ekonomi. Pembelajaran tersebut disajikan di sekolah mulai dari kelas rendah sampai kelas atas.

IPS adalah serangkaian kegiatan pembelajaran di sekolah yang 
mempelajari isu-isu sosial yang berkembang di masyarakat yang memuat keadaan geografis, perkembang sejarah dan kegiatan ekonomi masyarakat. Pembelajaran IPS akan terus berkembang karena kehidupan masyarakat global selalu mengalami perubahan. Oleh karena itu pembelajaran IPS dirancang untuk mengembangkan pengetahuan, pemahaman dan kemampuan analisis terhadap kondisi sosial masyarakat dalam memasuki kehidupan bermasyarakat yang dinamis.

Dengan demikian dapat disimpulkan bahwa Ilmu Pengetahuan Sosial merupakan kajian ilmu-ilmu sosial secara terpadu yang disederhanakan untuk pembelajaran di sekolah dan mempunyai tujuan agar peserta didik dapat mengamalkan nilainilai (values) sehingga dapat menjadi warga negara yang baik berdasarkan pengalaman masa lalu yang dapat dimaknai untuk masa kini, dan diantisipasi untuk masa yang akan datang.

\section{Hakikat Model Pembelajaran}

Mulyani Sumantri (1999:42)

menyimpulkan "Model Pembelajaran adalah karangka konseptual yang melukiskan prosedur yang sistematis dalam mengorganisasikan pengalaman belajar untuk mencapai tujuan pembelajaran". Kardi dan Nur (2011:142) menyimpulkan "Model Pembelajaran mempunyai makna yang lebih luas daripada strategi,metode,atau prosedur.

Berdasarkan beberapa pendapat di atas, maka moel pembelajaran merupakan suatu perencanaan atau suatu pola yang digunakan sebagai pedoman dalam merencanakan pembelajaran di kelas.

\section{Role Playing}

Role Playing diartikan mengacu pada perubahan perilaku seseorang untuk menjalankan peran, baik peran sosial sebagai masyarakat ataupun peran khayalan seperti di dalam teater. Sani (2013:5) memberikan pengertian tentang model pembelajaran Role Playing bahwa Role Playing dalam dunia pendidikan merupakan salah satu model penguasaan bahan-bahan pelajaran melalui pengembangan imajinasi dan penghayatan murid. Pengembangan imajinasi dan penghayatan ini dilakukan murid dengan memerankan tokoh hidup dalam kehidupan nyata ataupun sebagai benda mati. Model pembelajaran Role Playing juga dikenal dengan nama model pembelajaran bermain peran. Model pembelajaran ini 
dimulai dengan pengorganisasian kelas secara berkelompok. Masing-masing kelompok memperagakan atau menampilkan skenario yang telah disiapkan guru. Murid diberi kebebasan berimprovisasi namun masih dalam batas scenario yang telah dibuat guru.

Model pembelajaran Role Playing digunakan untuk menjelaskan sikap, konsep, rencana, menguji penyelesaian masalah, serta membantu murid menyiapkan situasi nyata, dan memahami situasi social secara lebih mendalam. Bermain peran tidak dapat dilakukan secara spontan di kelas dengan persiapan yang terbatas.

Bermain peran sangat potensial digunakan mengapresiasikan perasaan, mengembangkan pemahaman seseorang terhadap perasaan dan perspektif orang lain, serta mendemonstrasikan kreatifitas dan imajinasi dengan memerankan tokoh hidup.

\section{METODE PENELITIAN}

Penelitian ini termasuk ke dalam jenis penelitian eksperimen semu yaitu suatu penelitian dimana peneliti secara sengaja memanipulasi suatu variabel (memunculkan atau tidak memunculkan suatu variabel) kemudian memeriksa efek atau akibat yang ditimbulkannya. Desain penelitian ini menggunakan "One Group Pre test - Post test".

Populasi dalam penelitian ini adalah seluruh siswa SD Inpres Bontomanai Kota Makassar sebanyak 163 siswa untuk keseluruhan dan sampel dalam penelitian ini adalah yang berjumlah 24 siswa, siswa laki-laki 11 orang dan siswa perempuan 13 orang. Instrumen dalam penelitian ini adalah tes berbentuk soal pertanyaan yang digunakan untuk pengukur pencapaian siswa setelah proses pembelajaran yang dilakukan akhir tindakan pada kelas eksperimen dan lembar observasi aktivitas siswa. Untuk menganalisis data yang diperoleh dari hasil penelitian akan digunakan analisis statistik deskriptif dan inferensial.

HASIL PENELITIAN DAN PEMBAHASAN

Pengaruh Penerapan Model pembelajaran Role Playing (Bermain Peran) pada Murid Kelas V SD Inpres Bontomanai Kota Makassar

Tabel 1. Analisis skor Pre-test dan Posttest

\begin{tabular}{|l|l|l|l|l|}
\hline No & $\begin{array}{l}\mathrm{X} 1 \\
(\text { Pre- } \\
\text { test })\end{array}$ & $\begin{array}{l}\mathrm{X} 2 \\
(\text { Post- } \\
\text { test })\end{array}$ & $\begin{array}{l}\mathrm{d}=\mathrm{X} 2 \\
-\mathrm{X} 1\end{array}$ & $\mathrm{~d}^{2}$ \\
\hline 1 & 40 & 65 & 25 & 625 \\
\hline
\end{tabular}




\begin{tabular}{|c|c|c|c|c|}
\hline 2 & 48 & 70 & 22 & 484 \\
\hline 3 & 50 & 70 & 20 & 400 \\
\hline 4 & 60 & 75 & 15 & 225 \\
\hline 5 & 50 & 70 & 20 & 400 \\
\hline 6 & 35 & 58 & 23 & 529 \\
\hline 7 & 90 & 95 & 5 & 25 \\
\hline 8 & 63 & 80 & 17 & 289 \\
\hline 9 & 80 & 93 & 13 & 169 \\
\hline 10 & 30 & 54 & 24 & 576 \\
\hline 11 & 40 & 60 & 20 & 400 \\
\hline 12 & 65 & 80 & 15 & 225 \\
\hline 13 & 65 & 83 & 18 & 324 \\
\hline 14 & 75 & 90 & 15 & 225 \\
\hline 15 & 70 & 85 & 15 & 225 \\
\hline 16 & 40 & 65 & 25 & 625 \\
\hline 17 & 48 & 70 & 22 & 484 \\
\hline 18 & 50 & 70 & 20 & 400 \\
\hline 19 & 60 & 75 & 15 & 225 \\
\hline 20 & 50 & 70 & 20 & 400 \\
\hline 21 & 40 & 65 & 25 & 225 \\
\hline 22 & 48 & 70 & 22 & 484 \\
\hline 23 & 50 & 70 & 20 & 400 \\
\hline 24 & 60 & 75 & 15 & 225 \\
\hline $\begin{array}{l}\text { JUM } \\
\text { LAH }\end{array}$ & 1306 & 1758 & 451 & 8589 \\
\hline
\end{tabular}

1. Mencari harga "Md" dengan menggunakan rumus:

$$
\begin{aligned}
\operatorname{Md} & =\frac{\sum d}{N} \\
& =\frac{451}{24} \\
& =18,79
\end{aligned}
$$

2. Mencari harga " $\sum X^{2} d$ " dengan menggunakan rumus:

$$
\begin{aligned}
\sum X^{2} d & =\sum d^{2}-\frac{\left(\sum d\right)^{2}}{N} \\
& =8589-\frac{(451)^{2}}{24} \\
& =8589-\frac{203401}{24} \\
& =8589-8475 \\
& =114
\end{aligned}
$$

3. Menentukan harga $t_{\text {Hitung }}$

$$
\begin{aligned}
\mathrm{t} & =\frac{M d}{\sqrt{\frac{\sum X^{2} d}{N(N-1)}}} \\
\mathrm{t} & =\frac{18,79}{\sqrt{\frac{114}{24(24-1)}}} \\
\mathrm{t} & =\frac{18.79}{\sqrt{\frac{114}{552}}} \\
\mathrm{t} & =\frac{18,79}{\sqrt{0,20}} \\
\mathrm{t} & =\frac{18,79}{0,44} \\
\mathrm{t} & =42,70
\end{aligned}
$$

4. Menentukan harga $t_{\text {Tabel }}$

Untuk mencari $\mathrm{t}_{\text {Tabel }}$ peneliti menggunakan tabel distribusi $\mathrm{t}$ dengan taraf signifikan $\alpha=$ Langkah-langkah dalam 0,05 dan $d . b=N-1=24-1=23$ maka diperoleh $\mathrm{t}_{0,05}=2,14$ 
Setelah diperoleh $t_{\text {Hitung }}=42,70$ dan $t_{\text {Tabel }}=2,14$ maka diperoleh $t_{\text {Hitung }}>t_{\text {Tabel }}$ atau 42,70 $>2,14$. Sehingga dapat disimpulkan bahwa $\mathrm{H}_{0}$ ditolak dan $\mathrm{H}_{\mathrm{a}}$ diterima. Ini berarti bahwa ada pengaruh dalam menerapkan model pembelajaran Role Playing (Bermain Peran) terhadap hasil belajar pada mata pelajaran IPS kelas V SD Inpres Bontomanai Kota Makassar.

Pada bagian ini akan diuraikan hasil yang ditemukan dalam penelitian. Hasil yang dimaksudkan yaitu kesimpulan yang diambil berdasarkan data yang terkumpul dan analisis data yang telah dilakukan.

Berdasarkan hasil pre-test, nilai rata-rata hasil belajar murid 54,41 dengan kategori yakni sangat rendah yaitu 4,17\%, rendah 54,17\%, sedang $16,66 \%$, tinggi $20,83 \%$ dan sangat tingggi berada pada presentase $4,17 \%$.. Melihat dari hasil presentase yang ada dapat dikatakan bahwa tingkat hasil belajar murid sebelum diterapkan model pembelajaran Role Playing (Bermain Peran) tergolong rendah.

Selanjutnya nilai rata-rata hasil post-test adalah 73,25 jadi setelah diterapkan model pembelajaran Role Playing (Bermain Peran) mempunyai hasil belajar yang lebih baik dibanding dengan sebelum penerapan model pembelajaran Role Playing (Bermain Peran). Selain itu persentasi kategori hasil belajar IPS murid juga meningkat yakni sangat tinggi yaitu 16,67\%, tinggi $70,83 \%$, sedang $8,33 \%$, rendah $4,17 \%$, dan sangat rendah berada pada presentase $0,00 \%$.

Berdasarkan hasil analisis statistik inferensial dengan menggunakan rumus uji t, dapat diketahui bahwa nilai thitung sebesar 42,70. Dengan frekuensi ( $\mathrm{dk}$ ) sebesar 24 - $1=23$, pada taraf signifikansi 5\% diperoleh $t_{\text {tabel }}=2,14$. Oleh karena $t_{\text {hitung }}$ $>t_{\text {tabel }}$ pada taraf signifikansi 0,05 , maka hipotesis nol $\left(\mathrm{H}_{0}\right)$ ditolak dan hipotesis alternative $\left(\mathrm{H}_{\mathrm{a}}\right)$ diterima yang berarti bahwa ada pengaruh dalam menerapkan model pembelajaran Role Playing (Bermain Peran) terhadap hasil belaja murid.

Hasil analisis diatas yang menunjukkan adanya pengaruh penerapan model pembelajaran Role Playing (Bermain Peran) sejalan dengan hasil observasi yang dilakukan. Berdasarkan hasil observasi terdapat perubahan pada murid yaitu pada awal kegiatan pembelajaran ada beberapa murid yang melakukan kegiatan lain atau bersikap cuek selama pembelajaran berlangsung. Hal ini dapat dilihat pada pertemuan pertama murid 
yang melakukan kegiatan lain sebanyak 2 orang, sedangkan pada pertemuan terakhir hanya 1 murid yang melakukan kegiatan lain pada saat permainan berlangsung. Pada awal pertemuan, hanya sedikit murid yang aktif mengikuti pembelajaran. Akan tetapi sejalan dengan diterapkannya metode bermain murid mulai aktif pada setiap pertemuan.

Hasil observasi menunjukkan banyaknya jumlah murid yang menjawab pada saat diajukan pertanyaan dan murid yang mengajukan diri

untuk

melakukankegiatanpembelajaran.

Murid juga mulai aktif dan percaya diri untuk menyampaikan perasaan dan pendapatnya setelah melakukan kegiatan permainan, mereka mengaku senang dan sangat menikmati permainan yang dilakukan sehingga termotivasi untuk mengikuti pelajaran. Proses pembelajaran yang menyenangkan membuat murid tidak lagi keluar masuk pada saat pembelajaran berlangsung dan tidak lagi merasa bosan ataupun tertekan ketika mengikuti proses pembelajaran di kelas.

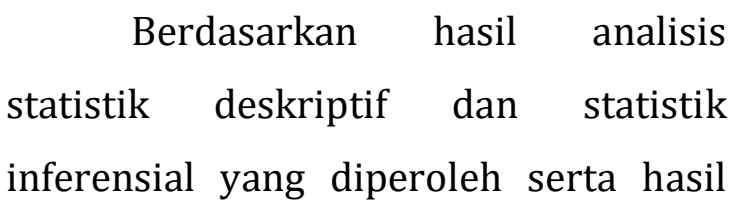

observasi yang telah dilakukan, dapat disimpulkan bahwa Ada pengaruh penerapan model pembelajaran Role Playing (Bermain Peran) terhadap hasil belajar pada mata pelajaran IPS siswa kelas V SD Inpres Bontomanai Kota Makassar.

\section{KESIMPULAN}

Simpulan yang lebih rinci berkaitan pelaksanaan pembelajran dengan menggunakan strategi pembelajran Role Playing (Bermain Peran) pada murid kelas V SD Inpres Bontomanai Kota Makassar sebagai berikut : (1) Berdasarkan data yang diperoleh dapat disimpulkan bahwa secara umum hasil belajar murid kelas V SD Inpres Bontomanai Kota Makassar sebelum penerapan strategi pembelajaran Role Playing (Bermain Peran) dikategorikan rendah. Hal ini ditunjukkan dari perolehan persentase hasil belajar siswa yaitu sangat rendah yaitu $4,17 \%$, rendah $54,17 \%$, sedang 16,66\%, tinggi 20,83\% dan sangat tingggi berada pada presentase 4,17\%. (2) Berdasarkan data yang diperoleh dapat disimpulkan bahwa secara umum hasil belajar murid kelas V SD Inpres Bontomanai Kota Makassar setelah menerapkan strategi pembelajaran Role Playing (Bermain 
Peran) berpengaruh terhadap hasil belajar murid kelas $\mathrm{V}$ SD Inpres Bontomanai Kota Makassar dapat dilihat dari perolehan persentase yaitu sangat tinggi $16,67 \%$, tinggi $70,83 \%$, sedang $8,33 \%$, rendah $4,17 \%$, dan sangat rendah berada pada presentase 0,00\%. (3) Berdasarkan uji hipotesis yang telah dilakukan dapat disimpulkan bahwa penerapan strategi pembelajaran Role Playing (Bermain Peran) berpengaruh terhadap hasil belajarsetelah diperoleh $t_{\text {Hitung }}=42,70$ dan $t_{\text {Tabel }}=2,14$ maka diperoleh $t_{\text {Hitung }}>$ $\mathrm{t}_{\text {Tabel }}$ atau $42,70>2,14$.

Berdasarkan temuan yang berkaitan hasil penelitian penerapan strategi pembelajaran Role Playing (Bermain Peran) yang mempengaruhi hasil belajarmurid kelas V SD Inpres Bontomanai Kota Makassar, maka dikemukakan beberapa saran sebagai berikut: (1) Kepada para pendidik khususnya guru SD Inpres Bontomanai Kota Makassar, disarankan menerapkan strategi pembelajaran Role Playing (Bermain Peran) untuk membangkitkan minat dan motivasi siswa untuk belajar. (2) Kepada Peneliti, diharapkan mampu mengembangkan strategi pembelajaran Role Playing (Bermain Peran) ini dengan menerapkan pada materi lain untuk mengetahui apakah pada materi lain cocok dengan strategi pembelajaran ini demi tercapainya tujuan yang diharapkan. (3) Kepada calon Peneliti, akan dapat mengembangkan dan memperkuat strategi ini serta memperkuat hasil penelitian ini dengan cara mengkaji terlebih dahulu dan mampu mengadakan penelitian yang lebih sukses.

\section{DAFTAR PUSTAKA}

A.M. Sardiman. 2005. Interaksi dan Motivasi Belajar Mengajar. Jakarta: Rajawali press.

Aunurrahman. 2010. Belajar dan Pembelajaran. Bandung. Alfabeta.

B. Uno Hamzah. 2008. Perencanaan Pembelajaran. Jakarta: Bumi Aksar.

Departemen Agama. 2004. Standar Kompetensi Madrasah Ibtidaiyah. Jakarta: Direktorat Jenderal Kelembagaan Islam.

Departemen Agama. 2004. Proses Pembelajaran IPS di MI/SD.Jakarta: Direktorat Jenderal Kelembagaan Islam.

Dimyati dan Mudjiono. 2006. Belajar dan Pembelajaran. Jakarta: Rineka Cipta

Effendi, dkk.2009. Pengembangan Pendidikan IPS .Jakarta:Rineka cipta. 
Emzir. 2014. Metodologi Penelitian Pendidikan. Jakarta: PT. Rajagrafindo Persada.

Rusman. 2013. Model-Model Pembelajaran Berorientasi Mengembangkan Profesionalisme Guru. Jakarta: PT Raja Grafindo Persada.

Sahabuddin. 2007. Mengajar Dan Belajar. Makassar: Badan Penerbit UNM Makassar.

Sanjaya, Wina. 2008. Startegi Pembelajaran Berorientasi Standar Proses Pendidikan. Jakarta: Prenada Media.

Sugiyono. 2015. Metode Penelitian Pendidikan. Bandung: Alfabeta.

Trianto. 2010. Mengembangkan Model Pembelajaran Tematik. Jakarta: Prestassi Pustaka.
Tim Pengembang MKDP. 2011. Kurikulum \& Pembelajaran. Jakarta:Rajawali Pers.

Tim Penyusun FKIP Unismuh Makassar. 2014. Pedoman Penulisan Skripsi. Makassar: Panrita Press Unismuh Makassar.

Biantara Ardian. (2013). Pengaruh penggunaan Metode Role Playing Terhadap Hasil Belajar IPS Pada Siswa kelas V SD Negeri Blando 3 Kecamatan Mungkid Kabupaten Magelang. Naskah Publikasi. (online). (http://www.repositori.com.html, diakses 1 Mei 2016).

Syamsu Basri. (2000). Pengertian Model Pembelajaran Role Playing. (online). (http://www.sharingkuliahku.word press.com.html, diakses 1 Mei 2016). 